Ankara Univ. Vet. Fak. Derg.

30 (2) : 292-307, 1983

FARKLI DÜ\%EYLERDE ÜRE ICCEREN RASYONLARIN IJOGU ANADOLL KIRMIZISI SIC̈IRLARDA YEM TÜKETIMI, YEMDEN YARARLANMA

VE CANLI ACIRIIK ARTIŞI UZZERINE ETKISI

\title{
Irfan Çolpan*
}

The effects of different amounts of urea on feed intake, feed efficiency and live weight gain on Eastern Red young bulls

Summary: This experiment was carried out to investigate the effects of urea supplemented into the concentrate feed upon the feed intake, feed efficiency, and body weight gain of Eastern Anatolian Red young bulls.

In the experiment 40 Eastern Anatolian Red young bulls 2 and 2.5 years old were fed with urea supplemented concentrates and wheat straw as roughage. The levels of urea in the concentrates were $0.00 \%, 0.75 \%, 1.50 \%$ and $2.25 \%$. The experiment consisted of a ten day of initial and 112 days of fattening periods.

Animals fed with urea supplemented feed showed an increase in the consumption of concentrates and roughage while their body weight increased. After 112 days of feeding, the averaye daily feed intake for the feeding groups $I, I I, I I I$ and $I V$ were in the order of $7.445,7.462,7.417$ and $7.369 \mathrm{~kg}$.

Feed efficiency of the groups $I, I I, I I I$ and IV, were $10.169,9.832,10.225$ and $9.140 \mathrm{~kg}$, respectively.

Daily average body weight gains of the groups $I, I I, I I I$ and $I V$ were 732.14, 758.92, 723.21 and $806.25 \mathrm{~g}$, accordingly.

It is concluded that there are no significant differences betiveen the rations with vegetable proteins and rations with urea in respect of body weight gains of the animals and the usage of urea as $24.72 \%$ of the crude protein has no limiting effect on feed consumption.

Ozet: Kuvvetli yeme katzlan $\% 0.00,0.75,1.50$ ve 2.25 oranlarinda ürenin dört gruba ayrlan 2.0-2.5 yaşnda cantı ağırlıkları ortalama 183.05

* Dr. med.vet. A. L̇. Veteriner Fakültesi Hayvan Besleme ve Beslenme Hastalıkları Anabilim Dalı, Ankara-Turkey. 
kg olan, 40 baş Doğu Anadolu Kirmıžsı erkek sığırlarda yem tüketimi, yemden yararlanma ve canlı ağırlık artışı üzerine etkileri araştırıld?.

Kaba yem olarak hayvanlara saman verildi. On gün süren alıştırma döneminden sonra hayvanlar 112 giin besiye alındr.

Kaba ve kuvvetli yem tïketiminin, besi siiresi ilerledikģe artan canlı ağerlığa uygun olarak, giderek yükseldiği görüldü. Günlük ortalama yem tüketimi, grup I, II, III ve IV'deki hayvanlarda strasyyla $7.445 \mathrm{~kg}, 7.462 \mathrm{~kg}, 7.417$ $\mathrm{kg}$ ve $7.369 \mathrm{~kg}$ olarak bulundu.

Gruplar arasında, yemden yararlanma bakımından önemli bir fark görülmedi. Besi dönemi sonunda yemden yararlanma grup I, II, III ve IV'de siraszvla ortalama $10.169 \mathrm{~kg}, 9.832 \mathrm{~kg}, 10.225 \mathrm{~kg}$ ve $9.140 \mathrm{~kg}$ olarak bulundu.

Grup I, II, III ve IV'deki hayvanlarin besi dönemi sonunda günlük canlı ağırlık artış sirasigla $732.14 \mathrm{gr}, 758.92 \mathrm{gr}, 723.21 \mathrm{gr}$ ve $806.25 \mathrm{gr}$ olarak gözlendi.

Sonuf olarak, Doğu Anadolu Kirmızist erkek siğırlarında azot kaynağı olarak bitkisel protein ve üre kullanilmasınn canlı ağırllk arţsını ve kuvvetli yem karmalarndaki ham protein miktarnn da \% 24.72'sinin üre azotu ile karşılanmasınen yem tüketimini olumsuz yönde etkilemediğgi kanısına varnldı.

\section{Giriş}

Geviş getiren hayvanların fizyolojik özelliklcrinden yararlanmak amacı ile bu hayvanların rasyonlarına ham protein kaynağı olarak üre ve diğer azot bileşiklerini kullanma çalışmaları uzun zamandır yapılmaktadır. Son yıllarda bu yöndcki çalı̧̧malar daha da yoğunlaşmıştır. Bu tip çalışmalarda kullamılan fakat protcin nitcliğinde olmayan azotlu bileşikler, bitkisel ve hayvansal protcinlere göre daha ucuz protein kaynaklarıdır. Bu konuda çok ileri gitmiş olan Amerika Birleşik Devletleri'nde 1970'li yıllarda üçyüz bin ton olan yıllık ycmlik üre tüketimi giderek artmıs ve son yıllarda bir milyon ton düzcyinc çımıştır.

Ruminant rasyonlarına katılan basit azotlu bileşikler, rumende yüksek biyolojik değerli mikrobiyel proteinlere dönüşürler. Rumen sıvısı ilc birlikte sindirim kanalının ileri bölümlerine geçen mikroorganizmalar abomazusda vc incc barsakların ön kısımlarında sindirim enzimleri ctkisiyle amino asitlere kadar parçalanır ve emilirler (29, $30,33,34)$. Ürc, rumende üreaz etkisiyle hızla parçalanır. Ancak ürenin parçalanmasında açığa şıkan amonyağın protcin sentezinde 
genelliklc aynı hızla kullanılmadığı kabul edilmektedir. Sığırlarda, bakteriyel ürcaz etkisiyle dakikada $75-125$ gr üre parçalanabilmektedir (37). Rumende de saatte $3 \mathrm{gr}$ azot veya $6.5 \mathrm{gr}$ üre, $18-20 \mathrm{gr}$ mikrobiyel protein şekline $\varsigma$ cvrilebilmektedir $(43,44)$. Bu nedenle hayvanlara yüksek miktarda verilcn ürc rumende amonyak düzeyinin artmasına ve toksikasyona yol açabilmcktedir (20). Bu scbeplerden dolayı hayvanlara üreli rasyonların kısa aralıklarla verilmesi gerekir. Böylece alınan üre azotunun daha iyi değcrlendirilebildiği ve özellikle besi hayvanlarında daha yüksck canlı ağırlık artı̧ı sağladığı bildirilmektedir $(4,10,40)$.

Bazı araştırıcılar $(18,32)$, ruminantların besinin başlangıcında ürcli rasyonlarla beslendiğinde, canlı ağırlık artışında bir gerileme olduğunu, diğer bazı araştırıcılarda $(2,14,32)$ bu durumun besi süresince de devam ettiğini bildirmektedirler. Ancak ruminantlarda basit azotlu bileşiklerin proteinler gibi değerlendirildiği liabul edilmektcdir.

Encrji bakımından fakir bir bileşik olan ürcnin hidrolizi sonucu açığa çıkan amonyağın, protcin scntezinde kullanılabilmesi ancak rumen bakterilerinin enerji ihtiyacmm yeterli düzeyde karşlanmasına bağhdır. Bunun için ürenin uygun miktarda karbonhidrata sahip rasyonlarla verilmesi gercklidir. Üreli rasyonlarda karbonhidratlar, sadecc enerji kaynağı olarak değil, aynı zamanda rumende amino asit sentezlenmesi için gerekli olan C-iskeletini vermeleri bakımından da önem taşırlar.

Rumen mikroorganizmalarmun etkisiyle çok hızlı bir biçinde parçalanan basit şekcrler, maksimal üre değerlendirilmesi için elverişli değildirler. Nişasta basit şekerlere nazaran ürenin değerlendirilmesinde daha etkili bir karbonhidrat kaynağıdır (3). Bu nedenle ürenin, özcllikle nişasta yönünden zengin tane ycmlerden oluşan kuvvetli yem karmalarına katılmak suretiyle hayvanlara verildiği görülmektedir. Ayrıca ürenin daha çok kurutulmuş şeker pancarı posası ve melas gibi enerji bakımmdan zcngin yemlerle birliktc kullanıldığı görülmcktedir.

Kurutulmuş mclaslı şeker pancarı posasının gerek ürenin rumen mikroorganizmaları tarafindan daha iyi değcrlendirilmesini sağlaması gerekse ürenin hoşa gitmcyen lezzctini ortadan kaldırması bakımından iyi bir ortam meydana getirdiği görülmektedir (15).

Genç danalar üzerinde yapılan bir çalı̧̧mada, temeli arpadan oluşan düşük protcinli temel bir rasyon ile bu rasyona protein kay- 
nağı olarak üre - kurutulmuş melaslı şcker pancarı posası ilave cdilerck yapılan bir rasyon ve yerfistığı küspesi - pamuk tohumu küspesi katılarak hazırlanan diğer bir rasyon karşılaştırılmıştır. Dencme sonunda küspe ve üre alan gruplarda canlı ağırlık artışı ve yemin etki derecesinin arpa ile beslenen kontrol grubundan önemli dercede farklı olduğu görülmüştür (15).

Protein tasarrufu amacıyla ruminant rasyonlarına ne düzcyde üre katılabilcceği çeşitli araştırıcılar tarafindan incelenmiştir. Ùre miktarının genel olarak kuru maddesinde \% 1.0-1.5'dan fazla (12) ve kuvvetli yemin bileşiminde \% 2-3'den fazla olmaması bildirilmektedir (33).

Rasyon proteininin hangi oranlarda üre ile karşlanmasmun uygun olduğu geniş ölçüde araştırılmıştır. Gcnellikle hayvanların tüm azot ihtiyacının veya rasyondaki azot miktarının \% 25-33'ünün ürc azotundan sağlanabileceği kabul cdilmektedir (11, 29, 33).

Hereford rrkı erkek danalar üzerinde yapılan bir besi çalışmasında protein kaynağı olarak soya küspesinin yerine rasyonlarda \% 50,75 ve 100 oranında üre ve mısır unu ilave edildiğinde günlük canlı ağırlık artışının ürc miktarının yüksclmesinc paralel olarak düştüğü ve soya küspesinin yerine \% 100 oranında üre ve mısır unu konulan grupta büyümenin önemli derecede gerilediği saptanmıştır (42). Diğer taraftan bazı araştırıcılar $(22,45)$ azotun \% 20-30'unun üreden karşılanması halinde büyümenin yavaşladığını, bazı araştırıcılar (27) ise azotun \% 40'ının üre ilc karşılanmasının mümkün olduğunu bildirmektedirler.

Birçok araştırmada yüksck değerli bir bitkiscl protein olan soya küspesi ile ürenin rasyonlarda kullanılması üzcrinde çalıştıkları görülmektedir.

Bileşiminde yüksek miktarda mısır $(6,8,19,25)$ ve darı (17) bulunan rasyonlara azot kaynağı olarak soya küspesi veya üre katılmasının, besi sığırlarında canlı ağırlık artışı üzcrinde farklı etki yapmadığı, yalnız soya küspesi alan grupta yemin daha iyi değerlendirildiği bildirilmiştir (17). Pamuk tohumu küspesi veya ürc katılmış darılı rasyonlarla yapılan diğer bir araştırmada sığırların canlı ağırlık artışında önemli bir fark olmadığı bildirilmektedir (31).

Doğu Anadolu Kırmızısı ve Brown Swiss crkek danalar üzerinde yapılan bir araştırmada, her ırk için ayrı iki rasyon hazırlanmış ve gruplara kaba yem olarak \% 15 saman ve \% 85 şeker pancarı posa- 
sından oluşan karma ad libitum olarak verilmiştir. Kuvvetli yeme \% 15 soya küspesi veya eşdeğcr olarak \% 2 ürc katılmıştır. Sonuçların istatistik analizlerinde ürcli ve soyalı gruplar arasında canlı ağırlık artış ve yemden yararlanma yönünden önemli bir fark bulunmamiştır (46).

Bir yaşlı 64 baş Doğu Anadolu Kirmızısı erkek danalaı üzcrinde. yapılan bir besi araştırmasında yüksck ve düşük düzeyde enerji kapsayan besi rasyonlarında arpa kırmasının bir kısmının ycrine ayçiçeği ve pamuk tohumu küspcleri ve azot bakımindan eşdeğer düzcyde üre kullanılmıştır. Rasyonlar hayvanlara ad libitum olarak vcrilmiştir. Elde edilen sonuçlara göre kullamılan bitkiscl proteinlerle, üre azotu arasında yem tüketimi, canlı ağırlık arışı ve yemden yararlanma yönünden öncmli bir fark tesbit edilmemiştir (47).

Bu araştırma rasyonlarına farklı düzcylerde üre katılarak beslenen Doğu Anadolu Kırmızısı sığırların yem tüketimi, yemden yararlanma ve canlı ağırlık artışını incelemck amacıyla yapılmışıı.

\section{Materyal ve Metod}

Araştırma materyalini 2-2.5 yaşlı ve canlı ağırlıkları 158-206 kg arasında değişen 40 baş Doğu Anadolu Kırmızısı erkek sığırlar teşkil etmiştir.

Araştırma her biri on baş hayvandan oluşan 1 kontrol 3 deneme olmak üzere 4 grup üzcrinde yürütülmüştür.

Araştırmaya başlamadan hayvanlar sabah yeminden önce arka arkaya iki gün tartılmıs ve bulunan değcrlerin ortalaması besi başlangıç ağırlığı olarak kabul edilmiştir.

Araştırma gruplarının rasyonlarında kuvvetli yem karmasının samana oranı 3:1'dir. Kontrol grubuna verilen kuvvetli yem karmasına \% 0.00, deneme gruplarma (grup II, III, IV) verilen yem karmalarına ise $\% 0.75,1.50$ ve $\% 2.25$ oranlarında üre katılmıştır. Araştırmada kullanılan kuvvetli yem karmalarının bileşimleri Tablo l'de verilmiştir.

Deneme süresi, on günlük bir alıştırma dönemi ve 112 günlük (16 hafta) besi döneminden ibarettir. Deneme gruplarında bulunan hayvanların ürcli rasyonlara ahş̧ırılması amacı ilc yürütülen 10 günlük alıştırma döneminde kontrol grubuna üresiz. kuvvetli yem kar- 
Tablo I. Kuvvetli yem karmasının bileşimi (\%).

\begin{tabular}{|c|c|c|c|c|}
\hline \multirow[b]{2}{*}{ Yem maddesi } & \multicolumn{4}{|c|}{$G r u p$} \\
\hline & I & II & III & IV \\
\hline Ayçiçeği küspesi & 6 & 6 & 6 & -- \\
\hline Pamuk tohumu küspesi & 12 & 7 & - & - \\
\hline $\begin{array}{l}\text { Kurutulmus şeker pancarı } \\
\text { posası* }\end{array}$ & 50 & $5^{0}$ & 50 & 50 \\
\hline Misir & 39 & 15 & 15 & 5 \\
\hline Arpa & Io & 18.25 & $24 \cdot 50$ & $39 \cdot 75$ \\
\hline Kemik unu & $1 \cdot 5^{n}$ & 1.50 & $1 \cdot 5^{\circ}$ & 1.50 \\
\hline Vitamin karması** & 0.15 & 0.15 & 0.15 & 0.15 \\
\hline Mineral karması*** & 0.10 & 0.10 & 0.10 & 0.10 \\
\hline Tuz & $0.5^{\circ}$ & 0.50 & 0.50 & $0.5^{\circ}$ \\
\hline Urc $\left(\begin{array}{lll}\% & 46\end{array}\right)^{* * * *}$ & - & 0.75 & $\mathrm{I} \cdot 5^{0}$ & 2.25 \\
\hline Kireç taşi & 0.75 & 0.75 & 0.75 & 0.75 \\
\hline Sindirilebilir ham protein & 12.07 & 12.71 & 12.84 & 13.20 \\
\hline $\mathrm{NB} / \mathrm{kg}$ & $6 \div 7.85$ & 612.17 & $6+1.05$ & 602.92 \\
\hline SHP: NB & $I: j \cdot 1$ & $1: 4.8$ & $1: 4 \cdot 7$ & $\mathrm{r}: 4.6$ \\
\hline
\end{tabular}

* 32-35 melasli

** Rovimix 301, ticari, vitamin karması

*** Romin 2, ticari mineral karması

**** Üre: T.Zirai Donatım Kurumundan sağlanmıştır.

ması, dencme gruplarına isc yavaş yavaş yükseltilen miktarlarda üre verilmiştir. Bileşiminde \% 0.75, 1.50 ve 2.25 üre bulunan kuvvetli yem karmaları, üre bulunmayan kontrol yemi ilc ilk öncc $1 / 4$, sonra $2 / 4$ ve daha sonra $3 / 4$ oranlarında karıştırılmışlar ve elde edilen karışımların her biri sirasıyla 3 gün, 3 gün ve 4 gün süreyle hayvanlara yedirilmiştir. Böylecc ürcli rasyonlarla beslenecek hayvanlar üreye alıştırılmıştır.

Besi hayvanlarına her $100 \mathrm{~kg}$ canlı ağırlık için $3 \mathrm{~kg}$ rasyon (kuvvetli yem karması + saman) hesaplanmıs ve verilen yemlerin tüketilme durumları takip edilerek hayvanlara verilcn yem miktarı \% 10 oranında arttırılmış veya cksiltilmiştir. Bu uygulamaya bütün besi süresince devam edilmiştir.

Her gün tazc olarak 3 kısım kuvvetli yem karması 1 kısım samanla karıştırılarak sabah ve akşam olmak üzere iki öğün halinde hayvanlara verilmiş ve bir önceki günden artan yem miktarı tartılarak tcsbit edilmiştir.

Hayvanlar grup yemlemesine tabi tutulmuş olup yem tüketimi grup ortalaması olarak saptanmıştır. Otomatik suluklarla hayvanlara içebildikleri kadar su verilmiştir.

Gruplarda yem tüketimi ikişcr haftalık aralıklarla hesaplanmıştır. Canlı ağırlık artışı ise 14 günde bir her sabah yemlemeden önce hayvanların ferdi tartıları yapılarak tesbit edilmiştir. 
Rasyonların hazırlanmasında kullanılan ycm maddelerinin, samanın ve kuvvetli yem karmalarmın ham besin maddeleri miktarı Weende analiz metoduna, lignin miktarı VanSoest (51) metoduna göre tayin cdilmiştir. Brüt enerji düzeyi ise Gallenkamp Ballistik Bomb Kalorimeter ile Mcal $/ \mathrm{kg}$ olarak belirtilmiştir.

Sonuçların istatistik analizleri ve grupların ortalama değeri arasındaki farkların önemliliği variyans analiz metodu ile yapılmıştır (13). Grup ortalamaları arasındaki farkların istatistik öncm kontrolünde en az önemli fark (LSD) metodu uygulanmıştır (28).

\section{Bulgular}

Araştırmada kullanlan rasyonlara katılan yem maddelerinin, kuvvetli yem karmalarının ve kaba yemin Weende analiz metodu ile saptanan ham besin maddeleri miktarlarına ait değerler Tablo 2 ve 3 'de gösterilmektcdir.

Yem tïketimi ve yemden jararlanma:

Araştırmada grup yemlemesi uygulanmı̧ ve ikişer haftalık araliklarla tesbit edilen verilerden hesaplanan yem tüketimi ile ilgili değcrlcr Tablo 4'de gösterilmektedir.

Araştırma gruplarında yemden yararlanma dört haftalık ycm tüketimi üzcrinden hesaplanmı̧ ve clde cdilen değerler Tablo 5'de verilmiştir.

\section{Canlı ağırlık artısı:}

Araşturmada grupların beslenmesinde kullanılan rasyonlara protein kaynağı olarak $\% 0.00,0.75,1.50$ ve $\% 2.25$ oranlarında üre katılmıştır. Hayvanların besi başlangıcında ve besi süresince 14 gün bir ferdi tartılarla canlı ağırlıkları tesbit edilmiştir. Gruplarda besi başlangıcı ve besinin çeşitli dönemlerindeki canlı ağırlıkları ile ilgili değcrler Tablo 6'da verilmiştir. Bu özelliklere ait variyans analizi sonuçları da aynı tabloda gösterilmiştir. Ayrıca gruplarda yem tüketimi ve canlı ağırlık artı̧ları ile ilgili değerler Tablo 7'de özetlenmiştir.

Araştırma süresincc grupların canlı ağırlık ortalamaları şekil 1 'de görülmcktedir. 
Tablo 2. Ycm maddelerinin ham besin maddeleri içeriği ve brüt enerji miktarı.

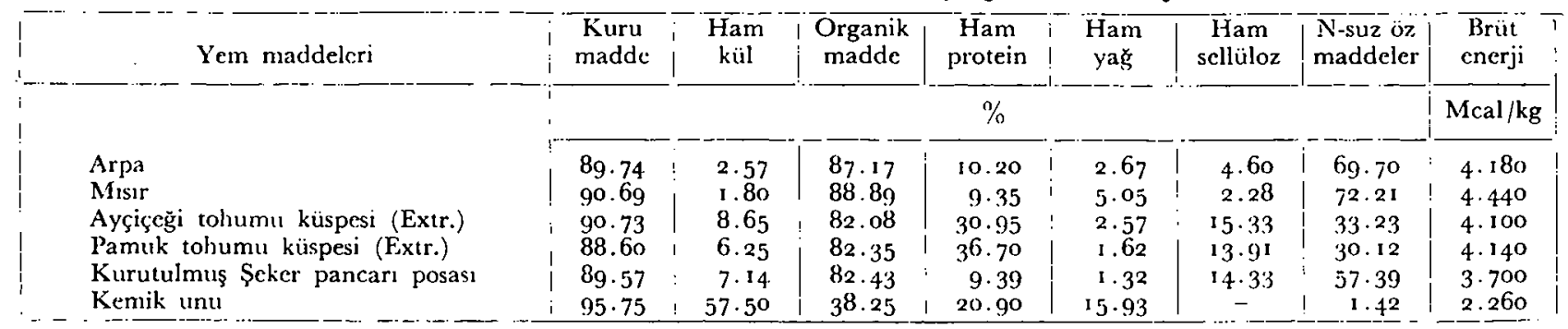

Tablo 3. Kuvvetli yem karmalarının ve kaba yemin ham besin maddeleri içeriği ve brüt enerji miktarı.

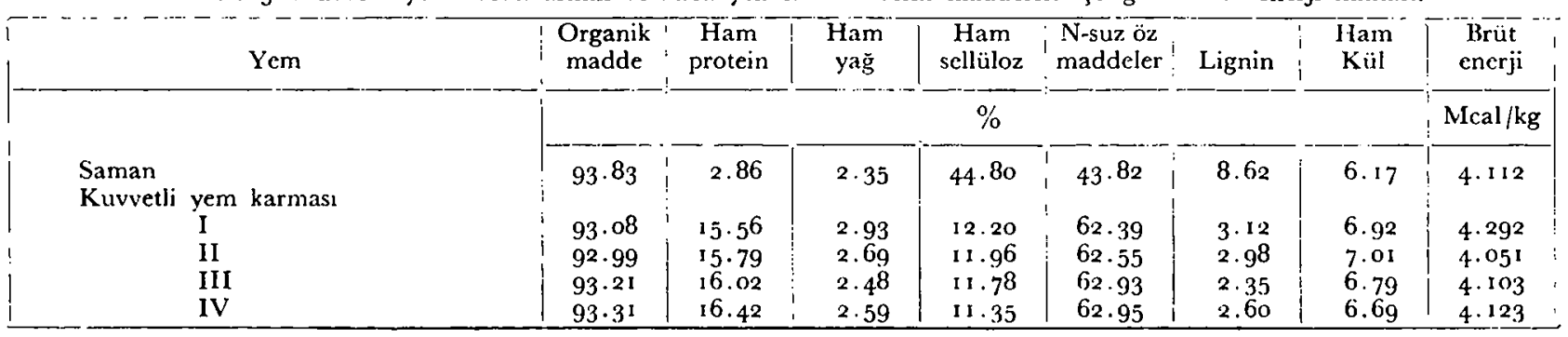


Tablo 4. Gruplarda yem tüketimi (Kurumadde), kg/gün.

\begin{tabular}{|c|c|c|c|c|c|c|c|c|c|c|c|c|}
\hline \multirow[b]{2}{*}{ Dönemler } & \multicolumn{3}{|c|}{ Grup I } & \multicolumn{3}{|c|}{ Grup II } & \multicolumn{3}{|c|}{ Grup III } & \multicolumn{3}{|c|}{ Grup IV } \\
\hline & $\begin{array}{c}\text { Kaba } \\
\text { yem }\end{array}$ & $\begin{array}{c}\text { Kuvvetli } \\
\text { yem }\end{array}$ & Toplam & $\begin{array}{c}\text { Kaba } \\
\text { yèm }\end{array}$ & $\mid \begin{array}{c}\text { kuvvetli } \\
\text { yem }\end{array}$ & Toplam & $\begin{array}{c}\text { Kaba } \\
\text { yem }\end{array}$ & $\left.\right|_{\substack{\text { Kem } \\
\text { yetli }}}$ & Toplam & $\begin{array}{c}\text { Kaba } \\
\text { yem }\end{array}$ & $\begin{array}{c}\text { Kuvvetli } \\
\text { yem }\end{array}$ & Toplam \\
\hline $\begin{array}{l}1 .-2 . \\
2 .-4 a f t a \\
4 .-6 . \quad ", \\
6 .-8 . \quad ", \\
8 .-10 . \quad ", \\
10 .-12 . \quad ", \\
12 .-14 . \quad ", \\
14 .-16 . \quad "\end{array}$ & $\begin{array}{l}1.755 \\
1.767 \\
1.779 \\
1.859 \\
1.833 \\
1.902 \\
2.008 \\
1.983\end{array}$ & $\begin{array}{l}5 \cdot 265 \\
5 \cdot 303 \\
5 \cdot 339 \\
5 \cdot 5^{80} \\
5 \cdot 502 \\
5 \cdot 709 \\
6.026 \\
5 \cdot 95^{0}\end{array}$ & $\begin{array}{l}7.020 \\
7.070 \\
7.118 \\
7.439 \\
7.335 \\
7.611 \\
8.034 \\
7.933\end{array}$ & $\begin{array}{l}1.75 \mathrm{I} \\
1.760 \\
1.771 \\
1.853 \\
1.845 \\
1.896 \\
2.021 \\
2.024\end{array}$ & $\begin{array}{l}5 \cdot 255 \\
5 \cdot 281 \\
5 \cdot 315 \\
5 \cdot 562 \\
5 \cdot 538 \\
5.689 \\
6.063 \\
6.072\end{array}$ & $\begin{array}{l}7.006 \\
7.041 \\
7.086 \\
7.415 \\
7.383 \\
7.585 \\
8.084 \\
8.096\end{array}$ & $\begin{array}{l}1.747 \\
1.756 \\
1.766 \\
1.822 \\
1.842 \\
1.887 \\
2.023 \\
1.988\end{array}$ & $\begin{array}{l}5.241 \\
5.270 \\
5 \cdot 300 \\
5 \cdot 468 \\
5 \cdot 527 \\
5.664 \\
6.070 \\
5.965\end{array}$ & $\begin{array}{l}6.988 \\
7.026 \\
7.066 \\
5.468 \\
7.369 \\
7.551 \\
8.093 \\
7.953\end{array}$ & $\begin{array}{l}1.723 \\
1.733 \\
1.756 \\
7.290 \\
1.805 \\
1.884 \\
2.018 \\
2.006\end{array}$ & $\begin{array}{l}5.171 \\
5.200 \\
5.269 \\
1.810 \\
5.418 \\
5.655 \\
6.055 \\
6.021\end{array}$ & $\begin{array}{l}6.894 \\
6.933 \\
7.025 \\
7.242 \\
7.223 \\
7.539 \\
8.073 \\
8.027\end{array}$ \\
\hline $\begin{array}{l}\text { Besi süresince } \\
\text { ortalama kuru } \\
\text { mad.tüketimi }\end{array}$ & $1.86 \mathrm{I}$ & $5 \cdot 5^{8} 4$ & $7 \cdot 445$ & I. 865 & 5.597 & $7 \cdot 4^{62}$ & I. 854 & $5 \cdot 5^{6} 3$ & $7.4^{17}$ & I. 842 & 5.527 & $7 \cdot 3^{69}$ \\
\hline
\end{tabular}

Tablo 5. Gruplarda ycmden yararlanma.

\begin{tabular}{|c|c|c|c|c|}
\hline & \multicolumn{4}{|c|}{$G r u p$} \\
\hline & I & II & III & IV \\
\hline 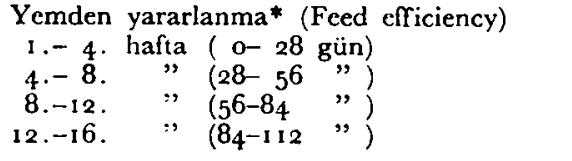 & $\begin{array}{r}12.204 \\
10.171 \\
9.141 \\
9.161\end{array}$ & $\begin{array}{r}10.250 \\
8.33^{0} \\
11.029 \\
9.721\end{array}$ & $\begin{array}{r}12.74^{\circ} \\
8.3^{\circ 0} \\
10.3^{80} \\
9.601\end{array}$ & $\begin{array}{r}\text { 10.610 } \\
8.287 \\
8.311 \\
9.35^{2}\end{array}$ \\
\hline $\begin{array}{l}\text { Besi süresince her kg canlı ağırlık artışı için } \\
\text { tüketilen yem (kurumadde), kg }\end{array}$ & 10.169 & $9.83^{2}$ & 10.255 & 9.140 \\
\hline
\end{tabular}

* Bir kilogram canlı ağırlık artısıı için tüketilen yem (kurumaddc), kg. 
Tablo 6. Gruplarda ortalama canlı ağırlıklar (kg) ve variyans analiz sonuçları.

\begin{tabular}{|c|c|c|c|c|c|c|c|c|c|}
\hline \multirow{3}{*}{ Özellik } & \multicolumn{9}{|c|}{$G r u p$} \\
\hline & \multicolumn{2}{|c|}{ I } & \multicolumn{2}{|c|}{ II } & \multicolumn{2}{|c|}{ III } & \multicolumn{2}{|c|}{ IV } & \multirow[b]{2}{*}{$\mathbf{F}$} \\
\hline & $\bar{X}$ & $S \bar{x}$ & $\bar{X}$ & $S \bar{x}$ & $\mathbf{X}$ & $\mathrm{S} \overline{\mathbf{x}}$ & $\bar{x}$ & $\mathbf{S x}$ & \\
\hline 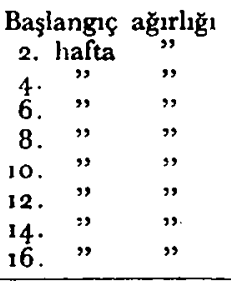 & $\begin{array}{l}183.8 \\
193.9 \\
199.5 \\
204.9 \\
219.0 \\
232.4 \\
241.4 \\
252.3 \\
265.8 \\
\end{array}$ & $\begin{array}{l}4 \cdot 04 \\
3 \cdot 84 \\
3 \cdot 69 \\
3 \cdot 75 \\
3 \cdot 97 \\
4 \cdot 30 \\
4 \cdot 57 \\
4 \cdot 78 \\
5 \cdot 59\end{array}$ & $\begin{array}{l}182.0 \\
191.4 \\
200.0 \\
209.8 \\
224.7 \\
233.5 \\
243.7 \\
254.0 \\
267.0 \\
\end{array}$ & $\begin{array}{l}4 \cdot 62 \\
4.84 \\
4 \cdot 35 \\
4 \cdot 96 \\
5 \cdot 41 \\
5 \cdot 70 \\
6.62 \\
6.84 \\
7 \cdot 53 \\
\end{array}$ & $\begin{array}{l}182.8 \\
191.7 \\
198.2 \\
207.9 \\
221.3 \\
231.1 \\
240.4 \\
250.0 \\
263.8\end{array}$ & $\begin{array}{l}4.62 \\
4.63 \\
5.63 \\
6.60 \\
6.53 \\
6.56 \\
7.58 \\
7.55 \\
8.29 \\
\end{array}$ & $\begin{array}{l}183.6 \\
193.3 \\
201.7 \\
212.9 \\
225.8 \\
238.2 \\
249.8 \\
262.2 \\
273.9 \\
\end{array}$ & $\begin{array}{l}4.60 \\
5.07 \\
4.93 \\
4.82 \\
5.25 \\
6.15 \\
6.11 \\
6.55 \\
6.55 \\
\end{array}$ & $\begin{array}{l}0.034- \\
0.069- \\
0.108- \\
0.428- \\
0.339- \\
0.290- \\
0.446- \\
0.665- \\
0.3^{8}-\end{array}$ \\
\hline
\end{tabular}

$\bar{X}=$ Ortalama değer

$\mathbf{S} \overline{\mathbf{x}}=$ Standart hata

$F=$ Fisher testi

Tablo 7. Gruplarda saptanan yem tüketimi ve canlı ağırlık artışı

(Onemlilik derecesi) ile ilgili ortalama değerler.

\begin{tabular}{|c|c|c|c|c|}
\hline \multirow[b]{2}{*}{ Özellik } & \multicolumn{4}{|c|}{$G \times u p$} \\
\hline & I & III & III & IV \\
\hline $\begin{array}{l}\text { Kaba yem (saman) tüketimi (kg/gün) } \\
\text { (kuru madde esasına göre) } \\
\text { Konsantre yem tüketimi (kg/gün) } \\
\text { (kuru madde esasına göre) } \\
\text { Toplam kurumadde tüketimi (kg/gün) } \\
\text { Besi süresinde tüketilen yem (kg) } \\
\text { Yemden yararlanma } \\
\text { Besi başlangı̧ ağırlığı (kg) } \\
\text { Besi sonu ağırlı̆̆ (kg) } \\
\text { Beside toplam canlı ağırlık artı̧ı (kg) } \\
\text { Besi süresinde günlük ortalama canlı ağır- } \\
\text { luk artı̧̧ (gr) }\end{array}$ & \begin{tabular}{|c|}
1.861 \\
$5.5^{84}$ \\
7.445 \\
833.840 \\
10.169 \\
183.8 \\
265.8 \\
82.0 \\
732.14
\end{tabular} & $\begin{array}{c}5 \cdot 597 \\
7.4^{62} \\
835 \cdot 744 \\
9.83^{2} \\
182.0 \\
267.8 \\
85.0 \\
75^{8.92}\end{array}$ & $\begin{array}{r}5.5^{63} \\
7.4^{17} \\
830.7^{04} \\
10.255 \\
182.8 \\
263.8 \\
81.0 \\
723.21\end{array}$ & $\begin{array}{r}5 \cdot 527 \\
7 \cdot 369 \\
825 \cdot 328 \\
9 \cdot 140 \\
183.6 \\
273 \cdot 9 \\
90.3 \\
806.25\end{array}$ \\
\hline
\end{tabular}




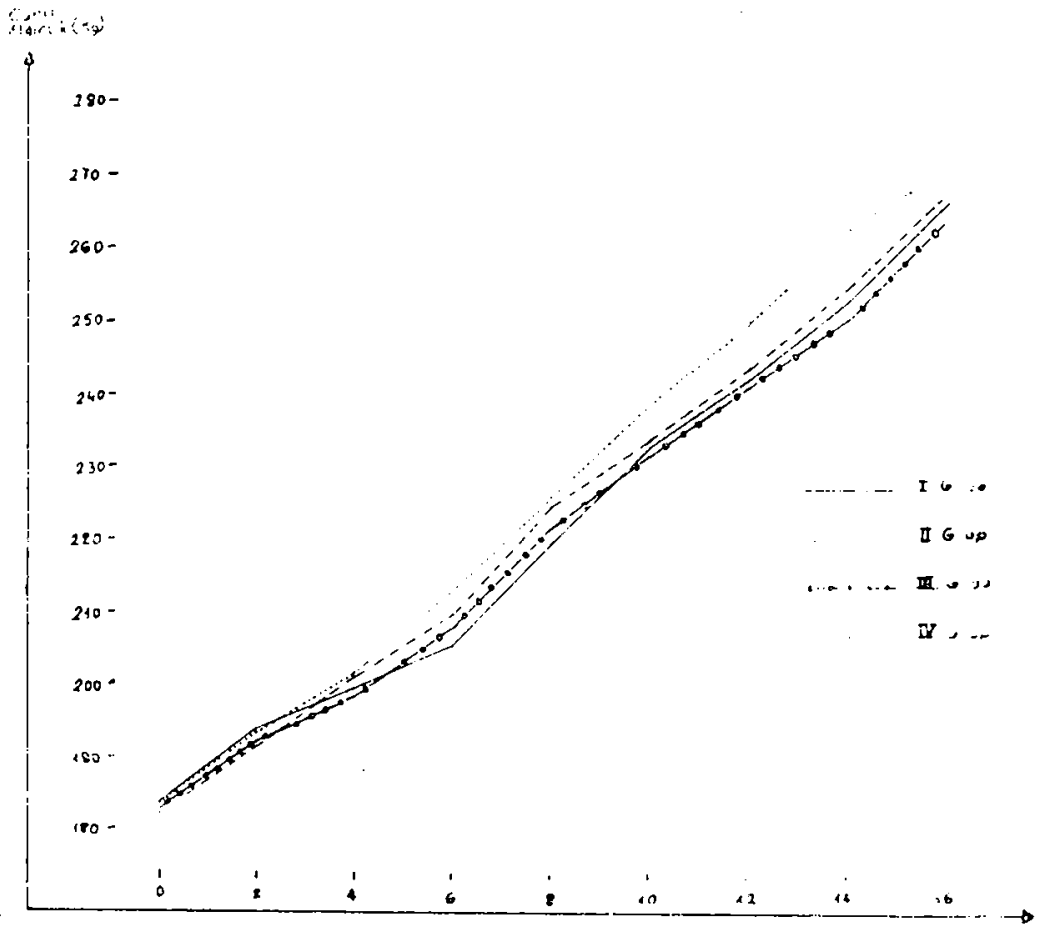

Şekil I. Gruplarda ortalama canlı ağırlık artışı.

\section{Tartışma ve Sonuç}

Gruplara verilen ve farkl düzeylerde $(\% 0.00,0.75,1.50$ ve $\%$ 2.25) ürc bulunan kuvvetli yem karmalarında ham besin maddeleri oranları ile $\mathrm{kg}$ yemdeki brüt enerji miktarlarının birbirlerine benzer olduğu görüldü (Tablo 3). Araştırmada kullanılan kuvvetli ycm karmalarında ham protein oranları yukardaki sıra ile $\% 15.56,15.79$, 16.02 ve $\% 16.42$ 'dir.

Grup yemlemesi uygulandığından araştırmanın yem tüketimi vc yemden yararlanma değerlerinin istatistik analizleri yapllmamı̧tır. Tablo 4 incelendiğindc kaba ve kuvvetli yem tüketiminin gruplarda, bcsi ilerledikçe artan canlı ağırlığa uygun olarak giderek yükseldiği görülmektedir. Araştırma sonunda gruplarda ortalama günlük yem tükctimi sırasıyla $7.445 \mathrm{~kg}, 7.462 \mathrm{~kg}, 7.417 \mathrm{~kg}$ ve $7.369 \mathrm{~kg}$ olarak bulunmuştur. Bu sonuçlardan, besi sığırları için hazırlanan kuvvetli 
yem karmalarındaki ham protein miktarının \% 24.72'sinin üre azotu ile karşlanmasının yem tükctimi üzerinde olumsuz bir ctki meydana getirmeyecç̆i anlaşılmıştır.

Araşturmanın çeşitli dönemlerinde gruplarda bir kg canlı ağırlık artı̧ı için tüketilen yem miktarlarını gösteren Tablo 5 incclendiğinde, gruplar arasında önemli bir farkın bulunmadığı anlaşılmaktadır. Gruplarda bir kg canlı ağırlık artı̧ıı için tükctilen ortalama yem miktarı, besi dönemi sonunda sırasıyla $10.169 \mathrm{~kg}, 9.832 \mathrm{~kg}, 10.255 \mathrm{~kg}$ ve $9.140 \mathrm{~kg}$ olarak hesaplanmıştır.

Bazı araştırmalarda kuvvetli yem karmalarına protein kaynağ olarak soya küspesi katılmasının (17) veya bu gibi karmalarda ürenin bitkisel proteinlerlc birlikte kullanılmasının (50), yemin değerlendirilme derecesi üzerinde olumlu etki gösterdiği bildirilmekte ve ürenin yem tüketini ve ycmden yararlanma üzerinde olumsuz bir etki göstermediği çoğunlukla kabul edilmektedir $(7,9,26,38,39,46,47)$.

Canlı ağırlık artışlarına ilişkin ortalama değerleri ve variyans analiz sonuçlarını gösteren Tablo 6 incelendiğinde, rasyonlarda azot kaynağı olarak bitkisel protein veya üre kullanılmasının canlı ağırlık artışını önemli derecede etkilemediği görülmektedir. Gruplarda 112 günlük besi dönemi sonunda elde cdilen toplam canlı ağırlık artısı sirasıyla $82.0 \mathrm{~kg}, 85.0 \mathrm{~kg}, 81.0 \mathrm{~kg}$ ve $90.3 \mathrm{~kg}$, günlük ortalama canlı ağırlık artışı sırası ile $732.14 \mathrm{gr}, 758.92 \mathrm{gr}, 723.21 \mathrm{gr}$ ve $806.25 \mathrm{gr}$, olarak hesaplanmıştır. Bileşiminde \% 2.25 üre kapsayan kuvvetli yem karmasi ile beslenen grupta besi sonu elde edilen toplam canlı ağırlık artışı ve günlük ortalama canlı ağırlık artışı değerleri diğer gruplardan yüksck olmakla beraber, gruplar arasındaki farklılıklar istatistik bakımdan önemli bulunmamıştır.

Kuvvetli yem karmalarına azot kaynağı olarak katılan soya $(5,6,7,8,19,21,25,35,36,48,49)$, pamuk tohumu ve yerfistığı $(15,16,31)$ küspeleri gibi bitkisel proteinlerin yerine çeşitli düzeylerde üre kullanılmasının besi sığırlarında canlı ağırlık artı̧̧ı üzcrinde olumsuz etki göstermediği çeşitli araştırıcılar tarafından bildirilmektedir. Hereford erkck danalarla yapılan bir besi araştırmasında, protein kaynağı olarak kaba yeme ilave edilen soya küspesi yerine $\% 50,75$ ve $\% 100$ oranında üre ve mısır unu katıldığında yüksclen ürc miktarına paralel olarak günlük canlı ağırlık artı̧ıının düştüğü, soya küspesinin yerine $\% 100$ oranında üre ve mısır unu katılması halinde isc büyümenin önemli derecede gerilediği saptanmıştır (42). Söz konusu araştırma- 
nun sonuçlarına göre rasyondaki total azotun \% 20'sinin üreden sağlanmasının besi performansı üzerinde olumsuz etki göstermediği, fakat üre miktarının \% 28'e çıarılması halinde büyümenin önemli derecede gerilediği bildirilmiştir. Bazı araştırıcılar rasyondaki azotun \% 20-30'unun ürcden karşılanması halinde büyümenin yavaşladığını $(22,45)$, bazı araşturıcılar ise \% 25'inin (41), hatta \% 40' 1 mı (27) üre ile karşılanmasının mümkün olduğunu bildirmektedirler. Bu araştrrmada 112 gün süren besi dönemi sonunda günlük ortalama canlı ağırlık artışı, bitkisel proteinlerle beslenen kontrol grubunda 732.14 gr olduğu halde, rasyon azotunun \% 24.72'si üre azotu ile karşlanan 4. grupta $806.25 \mathrm{gr}$ olduğu tesbit cdilmiştir. Iki grup arasındaki 74.11 gramlik fark istatistik bakımdan önemsiz bulunmuştur. Bu sonuçlara göre besi sığırları için hazırlanan kuvvetli yem karmalarında tüm azotun \% 25'inin ürc azotu ile karşlanmasının mümkün olabileceği anlaşılmaktadır.

Doğu Anadolu Kırmızısı sığırlar üzerinde üre ile yapılan iki besi denemesinden de bu çalışmada elde edilen değerlere benzer değerler elde edilmiştir $(46,47)$.

Nitekim üresiz rasyonlarla Doğu Anadolu Kırmızısı sığırlar üzerinde yapılan çeşitli denemelerde $(1,23,24)$ günlük ortalama canlı ağırlık artışının üreli rasyonlarla yapılan çalışma sonuçları ile uyum halinde olduğu görülmektedir.

Sonuç olarak Doğu Anadolu Kırmızısı besi sığırları rasyonlarına bitkisel proteinler yerine farklı düzeylerde kullanılacak ürenin canlı ağırlık, yem tüketimi ve yemden yararlanma üzerine olumsuz herhangi bir etkisi olamayacağı kanısına varıldı.

\section{Literatuir}

I- Akkulıc, M., Eltan, Ö. ve Eşcan, Ç. (1976): Kurutulmus kafes tavuğu gübresinin besi sığır rasyonlarında protein kaynağı olarak değerlendirilmesi. A.U. Vet.Fak.Derg., XXIII: $396-411$.

2- Armstrong, D.G. and Trinder, N. (1966): The use of urea and other non-protein nitrogenous substances in rations for ruminants. J.Univ.Newcastle-upon-Tyne Agr.Soc., 20: 3

(Alınmışur: Goodrich R.D., Meisk, J.C. and Gharib, F.H. 1972. Utilization of urea by ruminants. World Rev.J.Product., 8: 54-69).

3- Bloomfield, R.A., Muhrer, M.E. and Pfander, W.H. (1958): Relation of composition of energy source to urea utilization by rumen microoorganisms. J.Anim.Sci., 17: 1189-1190 (Abstr). 
4- Bloomfield, R.A., Welsch, C., Garner, G.B. and Muhrer, M.E. (1961): Effect of sixteen times a day feeding of urea utilization. J.Anim.Sci., 20: 926 (Abstr).

5- Boling, J.A., Bradley, N.W., Tucker, R.E. and Kratzer, D.D. (197 I): Supplemental nitrogen source and physical from of corn for finishing stecrs. J.Anim.Sci., 33: 895-898.

6- Bolsen, K.K., Hatfield, E.E., Garrigus, U.S., Lamb, P.E. and Doane, B.B. (1968): Effects of sources of supplemental nitrogen and minerals, level of chlortetracyline, moisture content of corn on the performance of ruminants fed all-concantrate diets. J.Anim.Sci., $27(2): 1663^{-1} 668$.

7- Bradley, N.W., Jones, Jr., B.M., Mitchell, Jr., G.E., and Little, G.O. (Ig66): Fat and urea in finishing rations for steers. J.Anim.Sci., 25: $4^{80-483}$.

8- Braman, W.L., Owens, F.N., Hatfield, E.E., Hixon, D.L. and Hal, G.A.B. (1971): Proteins levels and sources for steer calves fed all concentrate diets. J.Anim.Sci., 33: 276 (Abstr).

9- Brown, Paul, B., Hansard, L., Thrasher, D.M. and Robertson, L. (I966): Diammonium phosphate and urea in beef cattle rations. J.Anim.Sci., 25: 26I (Abstr).

1 o- Campbell, J.R., Howe, W.M., Martz, F.A., and Merilan, C.P. (1963): Effects of frequency of feeding on urea utilization and growth characteristics in dairy heifers. J.Dairy Sci., 46: $13^{1-1} 34$.

I I- Colenbrander, V.F., Muller, L.D., Wasson, J.A. and Cunningham, M.D. (1971): Effects of added urea and ammonium polyhosphate to corn slover silages on animol performance. J.Anim.Sci., 33: $1091-1096$.

12- Dilmen, S. $\left(1^{1963)}\right)$ :Ruminantların Beslenmesinde Yeni Gelişme ve Eł̧ilimler”. Türk Veteriner Hekimleri Odalar Birliği Merkez Konseyi Yayınları: 6. Akın Matbaası; Ankara.

13- Düzgüneş, O. (1963): "Bilimscl Araştrmalarda Istatistik Prensipleri ve Metodları". Ege Ưniversitcsi Matbaası: Izmir.

14- Embry, L.B., and Swan, W.S. (1976): Soybean meal and urca supplements with corn silage at various stages of feeding for calves. J.Anim.Sci., 42(5): 1369 (Abstr).

15- Fishwick, G., Fraser, J., Hemingway, R.G. and Parkins, J.T. (1973): A note on urea-containing molassed sugar bect pulp product as a protein concentrate for intensively-fed Friesian Steers. Anim. Prod., 17: 201-204.

I6- Furr, R.D., Hansan, K.R., Carpenter, J.A. and Sherrod, L.B. (1968) : Effect of different nitrogen sources and antibiotics in all-concentrate finishing rations. Proc.West.Sec. Amer.Soc.Animal Sci., 19: 97 (Alınmıştır: Church, D.C. 1972. Feedstuffs, November, 44: 40-42).

17- Greathouse, G.A., Schalles, R.R., Brent, B.E., Dayton, A.D. and Smith, E.F. (1974): Effects of levels and sources of protein on performance and carcass characteristics of steers fed all-concentrate rations. J.Anim.Sci., 39: 102-107.

I8- Hanke, H.E. and Jordan, R.M. (1965): Urea or soybean meal and alfalfa or dehydrated alfalfa as components of lamb finishing rations. Minncsota sheep and Lamb Fecders Day Report (Alınmıstır: Goodrich, R.D., Meiske, J.C. and Gharib, F.H. 1972. Utilization of urea by ruminants. World Review of Journal Porduction, 8: 54-69).

19- Haskins, B.R., Wise, M.B., Craig, H,B. and Barrick, E.R. (1967): Effects of levels of protein, sources of protein and an antibiotic on performance, carcass characteristics, rumen environment and liver ahscesses of steers fed all-concentrate rations. J.Anim.Sci., 26(I): $43^{0-434}$. 
20- Helmer, L.G. and Bartley, E.E. (1971): Progress in the utilization of urea as a protein replacer for ruminants. A review. J.Dairy Sci., 54: 25.51 .

2 I- Herd, D.B., Bradley, N.W., Little, G.O. and Overfieled, R. (1966): Utilization of nitrogen from different sources by beef steers fed ground ear com rations. J.Anim.Sci., 25: 260 (Abstr).

22- Kay, M., Macleod, N.A., McKiddie, G. and Philip, E.B. (1967): The nutrition of the early weaned calf. $X$. The effect of replacement of fish meal with either urea or ammonium aceiate on growth rate and nitrogen retention in calves fed ad libitum. Anim.Prod., 9:197-201.

23- Kendir, H.S., Şenel, S., Uludağ, N., Öznacar, R. ve Alı̨̧ K.. (1973): Doğu Anadolu kirmizisi Irkin Besi Performansi. TBTAK., IV. Bilim Kongresi, 5-8 Kasım 1973, Ankara.

24- Kendir, H.S., Müftüoğlu, Ş, ve Tekeş, M.A. (I 975) : Sunrsız ve smerl yemleme düzcyinde Doğu Anadolu Kirmiztst (D.A.K.) ve Montafon X D.A.K. erkek danalarm besi performanst. Lalahan Zoot.Araşt.Enst.Derg., $X V:$ 3-21.

25- Klopfenstein, T.J. and Cranfill, J.C. (1969): Liquid supplements for beef callle. J.Anim. Sci., 29: 177 (Abstr).

26- Kusnedelchev, M. and Vladimirov, I. (1973): Complete feeds with urea for the intensive fattening of calves and growing catlle. Zhivotnovudui Nouki, 10(7): 49-56 (Alınmıştır: Nutr. Abstr.Rev., 1975, 45(6): 570).

27- Leibholz, J. and Naylor, R.W. (1971): The effect of urea in the diet of the carly weaned calf on weight gain, nitrogen and sulphur balance and plasma uren and frec amino acid concentrations. Aust.J.Agr.Res., 22: 655-662.

28- Li, J.C.R. (196r): "Introduction to statistical inference". 3 rd.cd. Edwars Brathers, Inc. Ann.Arbor.: Michigan.

29- Maynard, L.A. and Loosli, J.K. (1969): "Animal Nutrition". 6th McGraw-Hill Book Company, Inc.: New York.

30- McDonald, P., Edwars, R.A. and Greenhalgh, J.F.D. (1 973): "Animal Nutrition". 2nd.Ed. Oliver and Boyd Edinburgh: London.

31- McGinty, D.D., Schake, L.M. and Marion, P.T. (I966): Protein supplements for allconcentrate rations. J.Anim.Sci., 25: 260 (Abstr).

32- Meiske, J.C. and Goodrich, R.D. (1 966): Non-protein nitrogen wilization with high and low energy rations. Proc. Minnesota Nutr.Cionf. 27: 30 (Alınmıstur: Goodrich, R.D., Meiske, J.C. and Gharib, F.H. (1972. Utilization of uren by ruminants. World Review of Journal Production, 8: 54-69).

33- Morrison, F.B. (1974): "Fecds and leeding". gth ed. The Morrison Publishing Company: Ontario.

34- Neumann, A.L. and Snapp, R.R. (1969): "Bcef Cattlc". 6tl ed. John Wilcy, Sons, Inc.: London.

35- Oltjen, R.R., Davis, R.E. and Hiner, R.L. (1965): Factors affecting performance und carcass characteristics of cattlc feed all-concentrate rations. J.Anim.Sci., 24: $192-197$.

$3^{6-}$ Pinney, D.O., Bradley, N.N., Little, C.O. and Overfield, J.R. (1966): Urea and soybean meal supplementation of corn-corn silage rations containing different levels of energ). J. Anim.Sci., 25: 260 (Abstr). 
37- Prokop, M.J., Woods: W. and Klopfenstein, T.J. (1971) : Factors effecting ruminal urease activity. J.Anim.Sci., 33: 1169 (Abstr).

38- Ramdall, R.P., Wallenius, R.W., Dyer, I.A. and Hillers, J.K. (1972): Usc of mo-

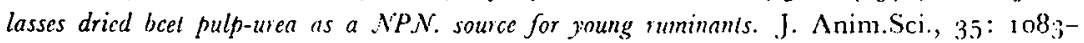
1086.

39- Raleigh, R.J. and Wallace, J.D. ( 1963$)$ : Effert of urea at different nitrogen levels on digestibility and on performance of growing stcers. fed low qualily food meadow roughage. J. Anim. Sci., 22: 330-334.

$4^{0-}$ Raleigh, R.J. and Wallace, J.D. ( 1965$)$ : Frequency of fecding and uren utilization by ruminants. J. Anim. Sci., 24: 595 (Abstr.)

$4^{1-}$ Reid, J.T. (1953): Urea as a prolein replacement for ruminants. A review. J.1)airy Sci., 36 : 955-996.

42- Robertson, J.B. and Miller, J.I. (1971): Ura and growing rations for beef stecr calves. J.Anim.Sci.. 32: $125^{1-1255 .}$

43- Schmanekow, N.A. (Ig60): Rumen produces vital mutrients. Red Book for 1957, 165177, USA. (Alınmışur: Dilmen, S. 1963. Ruminantlarm Beslenmesinde $Y_{\text {ent }}$ Gelişne ve Egilimler. Türk Veteriner Hekimleri Odalar Birliği Merkezi Konseyi Yayınları. Akın Matbaası, Ankara.

44- Shaw, J.C. (1975): Harnsloff in der Fïllerung, 1-1 10. Berlin, VEB Deutscher Landwirtschaftss-Verlag. (Alınmıştur: Dilmen, S. I963. Ruminantlarm Beslenmesinde Yeni Geliş̧me ve Eggilimler. Türk Veteriner Hekimleri Odalar Birliği Merkez. Konseyi Yayunlan. Akın Matbaası, Ankara.

45- Stobo, I.J.F., Roy, J.H.B. and Gaston, H.J. ( 1967 c) : The protein requirement of the ruminaut calf 3 . The ability of the calf weaned at five weeks of age to thilize urea given as a supplement to a low protein concentrate. Anim.Prod. 9: $155^{-165}$.

46- Şenel, H.S. (1971): Besi stğnn rasyonlarmdn üre ies scher pancan posast ile melas. Lalahan Zoot.Araşt.Enst.Derg., $\quad X I . \quad 28-39$.

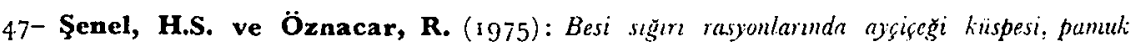
tohtemu kiuspesi ie ürenin protcin saplementi olarak liullantmast. Firat Univ.Vet.Fak.Derg., 2: $192-198$.

48- Thrasher, D.M., Scott, V.B. and Hansard, S.L. (1967): Protein supplementalion of concentrale rations for steer calics. J. Anim.Sci., 26:22.5 (Abstr).

49-- Tolman, W. and Woods, W. (1968): Lirea, suybean meal and corn as supplements in corn silage. J.Anim.Sci., 27: 1772 (Abstr).

50- Umunna, N.N., Hasimoğlu, S. Woods, W. and Klopfenstein, T. (*972): Combinations of proteins and urea. J.Anim.Sci., 35: 277 (Abstr).

$5^{1-}$ VanSoest, P.J. ( $\left(\mathrm{I}^{6} 6_{3}\right)$ : Lise of detergents in the analysis of fibrous feeds. A rapid method for determination of fiber and lignin. Assoc.. Off.Agr.Chem., 46: 829-835.

Yazı 28.4.198; gimui alınmıştr. 